\section{Effect of Plastic Mulch Color and Insecticides on Thrips Populations and Damage to Tomato}

\author{
Steve L. Brown ${ }^{1}$ and \\ James E. Brown ${ }^{2}$
}

Additional index words. Insecta, thrips, Thysanoptera

Summary. In each of 3 years, the average number of thrips in tomato (Lycopersicon esculentum L. cv. Mountain Pride) blooms was greater on tomatoes grown on white plastic mulch than on tomatoes grown on black plastic mulch, aluminum plastic mulch, or bare ground. Early season differences, however, diminished with time as plants grew and shaded a larger portion of plastic mulch. Weekly applications of 12 insecticide treatments failed to reduce thrips populations below that found in the control. No significant differences were found among treatments in the quantity, quality, or earliness of tomato yields. Incidence of tomato spotted wilt (vectored by some thrips species) was too low to detect statistical differences or determine the importance of thrips population in disease epidemiology. Western flower thrips (Frankliniella occidentalis) was the most common species found, followed by eastern flower thrips $(F$. tritici) and tobacco thrips ( $F$. fusca). Thrips control, in the absence of tomato spotted wilt, is not justified for the thrips populations encountered in this study.

$\mathrm{I}$ n Alabama, insect control programs for commercially grown tomatoes have been aimed primarily at a few lepidopterous larvae and hemipteran pests. Since tomato spotted wilt (TSW) virus, a disease of

University of Georgia, Extension Entomology Department, Tifton.

${ }^{2}$ Horticulture Department, Auburn University, Auburn, Ala. tomato and other crops, was first diagnosed in Alabama in 1986 (Hagan et al., 1987), tomato growers have initiated preventative spray programs for thrips control. In addition to being TSW virus vectors, thrips that feed primarily in blooms (western flower thrips and eastern flower thrips) may cause bloom abortion and distorted (catfaced) fruit (Watterson, 1985).

Since preventative sprays for thrips are applied immediately after transplanting seedlings into the field, thrips control programs are not compatible with integrated pest management strategies for other pests. Repeated early season spraying is thought to reduce beneficial insects and contribute to outbreaks of other pests.

Plastic mulch is used often in commercial tomato production. The effect of plastic mulch color on thrips populations has been studied by Scott et al. (1989) and Greenough (1985). In both studies, yellow sticky traps were used to monitor thrips populations. Scott et al. (1989) reported that populations of Frankliniella fusca, $F$. tritici, and Sericothrips variabilis were, on some sampling dates, lowest on aluminum-colored plastic mulch, highest on nonmulched, and intermediate on black plastic mulch. Effectiveness of the aluminum-colored mulch in reducing thrips populations generally diminished later in the season as lower leaves on the tomato plant shaded the mulch and traps were raised to accommodate increased plant height. Incidence of TSW was very low in the experiment, and no differences were found.

Greenough (1985) reported significantly fewer adult thrips on tomatoes grown on aluminum-colored plastic mulch than on tomatoes grown on black plastic mulch or nonmulched plots. A significant reduction in the incidence of TSW was reported by Greenough (1985) when aluminumcolored plastic mulch was used.

Our research was designed to examine the efficacy of insecticide and plastic mulch treatments for thrips control and the influence of thrips population density on tomato yield and quality.

\section{Materials and Methods}

This study was conducted at the E.V. Smith Research Center near Shorter, Ala., in 1988, 1989, and 1990. The soil was an Orangeburg sandy loam with a pH of 6.2. Each year thrips populations were monitored on tomatoes grown on black, white, and aluminum-colored plastic mulch and on bare ground. The only insecticides applied to these plots were those being evaluated for thrips control.

Plastic mulch was laid by hand before transplanting. The exposed plastic mulch strip was $\approx 1 \mathrm{~m}$ wide. The aluminum mulch treatment was prepared by laying black plastic in the field and spraying it with a 1 aluminum paint : 2 mineral spirits mixture.

A $20-\mathrm{cm}$ circle was cut out of the plastic for placement of each transplant into the soil. Each plot had 10 plants spaced $0.45 \mathrm{~m}$ apart. Adjacent plots were separated by $2.5 \mathrm{~m}$. Each treatment was replicated four times in a randomized complete block design. 'Mountain Pride' tomatoes were grown from seed in a greenhouse and transplanted to the field on 27 Apr. 1988, 25 Apr. 1989, and 28 May 1990.

Before planting, triple superphosphate and muriate of potash were incorporated into the soil according to soil test recommendations. At planting, $68 \mathrm{~kg} \mathrm{~N} / \mathrm{ha}$ was applied in the form of ammonium nitrate, and an additional $24 \mathrm{~kg}$ was applied at flowering. For weed control, trifluralin was applied preplant-incorporated at 0.84 $\mathrm{kg} \cdot \mathrm{ha}^{-1}$. Plants were staked and tied, a common commercial practice in Alabama. Plots were watered using an overhead, solid-set irrigation system. The fungicide chlorothalonil was applied weekly.

A different group of insecticide treatments was evaluated each year. In 1988 the insecticide treatments applied to tomatoes grown on bare ground were: acephate $(0.56 \mathrm{~kg}$ a.i./ ha); dimethoate (0.56 kg a.i./ha); and esfenvalerate $(0.056 \mathrm{~kg}$ a.i./ha). In 1989 the insecticide treatments applied to tomatoes grown on bare ground were: dimethoate $(0.56 \mathrm{~kg}$ a.i./ha); oxamyl $(0.28 \mathrm{~kg}$ a.i./ha and $0.56 \mathrm{~kg}$ a.i./ha); methamidaphos (0.56 $\mathrm{kg}$ a.i./ha); bifenthrin (0.07 $\mathrm{kg}$ a.i./ ha); and disulfoton (3.4 kg a.i./ha) in the furrow. In 1990 the insecticide treatments applied to tomatoes grown on bare ground were: acephate $(0.56$ $\mathrm{kg}$ a.i./ha) and methamidaphos (0.28 $\mathrm{kg}$ a.i./ha and $0.84 \mathrm{~kg}$ a.i./ha). Methamidaphos (0.84 $\mathrm{kg}$ a.i./ha) was also applied to tomatoes grown on aluminum-colored plastic mulch. With the exception of disulfoton, which was 
applied in the furrow at planting, all insecticides were applied weekly as foliar sprays using a $\mathrm{CO}_{2}$ backpack sprayer operating at $80 \mathrm{psi}$. The spray boom was configured with one spray nozzle above the row and a drop nozzle on each side of the row. The first application was made at first bloom, and the last application was made 1 week before the last sampling date.

In 1988 bloom samples were collected on 17, 24, and 31 May and 6, 14, and 22 June. In 1989 samples were collected on 25 and 31 May and 7, 14, and 22 June. The sample dates in 1990 were 3, 21, and 29 June and 6 and 13 July. Bloom samples were collected just before application of insecticides.

Thrips populations were recorded as numbers per five blooms. On each sample date, five blooms were collected from each plot and immediately placed in a labeled jar containing $80 \%$ ethyl alcohol. Blooms were selected at random, except end plants in each plot were avoided. Young blooms that were not fully open and old blooms that were beginning to dry out also were avoided. In addition to the samples from each plot, a composite sample of two blooms from each treatment was taken. Thrips collected from these composite samples were used for species identification.

In the laboratory, blooms immersed in alcohol were gently pulled apart with two dissecting needles. The resulting sample of flower parts and alcohol then was filtered through filter paper. The filter paper was observed through a dissecting microscope, and immature and adult thrips were counted.

Each year yields were recorded by date as number of fruit and fruit weight. Total number of fruit and fruit weights were classified as marketable, nonmarketable, and catfaced. The nonmarketable category included fruits that were not marketable for any reason other than being catfaced. In 1989 flooding in the test plots forced early termination of the experiment. Therefore, all fruit, regardless of size, were harvested on 26 June and categorized as small, medium, or large. The number of catfaced fruit also was recorded. Data were analyzed using Systat multivariate general linear hypothesis and Tukey's HSD test (Wilkinson, 1989).

\section{Results}

Seasonal averages of thrips populations for each year and the three years combined are shown in Table 1. The 1989 and 1990 thrips populations were greater on tomatoes grown on white plastic mulch than on tomatoes grown on black plastic mulch, aluminumcolored plastic mulch, or bare ground.

Averaging all sample dates, no differences were found among mulch treatments in 1988. However, on the first two sample dates in 1988, more thrips were found on the white plastic treatment than any other treatment (Table 2). There were no differences on the next four sample dates.

On the first two sample dates in 1989, more thrips were found in the white plastic treatment than any other treatment (Table 3). Thereafter, the number of significant differences among treatments decreased with time. On the last sample date, the thrips population in plots with white plastic was significantly greater than that found in the bifenthrin treatment only.

In 1990 significant differences in thrips populations were found only on the second sample date. On that date, the population found on tomatoes grown on white plastic mulch was greater than on all other treatments (Table 4).

Species of thrips were identified from composite samples taken on each sampling date in 1988 and 1990. In each year, F. occidentalis, $F$. tritici, and $F$. fusca were identified. Western flower thrips was the predominant species on the earlier sampling dates, but was replaced by Eastern flower thrips on later sampling dates. Tobacco thrips varied from 0 to $36 \%$ of the adult thrips population. Thrips species data are

Table 1. Seasonal average of thrips per five tomato blooms.

\begin{tabular}{|c|c|c|c|c|}
\hline \multirow[b]{2}{*}{ Treatment } & \multicolumn{4}{|c|}{ No. thrips ${ }^{x}$} \\
\hline & 1988 & 1989 & 1990 & $3-y r$ avg \\
\hline \multicolumn{5}{|l|}{ Mulch } \\
\hline White plastic & 40.9 a & $45.4 \mathrm{a}$ & $21.6 \mathrm{a}$ & $36.3 \mathrm{a}$ \\
\hline Black plastic & $28.0 \mathrm{a}$ & $8.0 \mathrm{~b}$ & $3.4 \mathrm{~b}$ & $14.1 \mathrm{ab}$ \\
\hline Bare-ground control & $17.2 \mathrm{a}$ & $18.8 \mathrm{~b}$ & $5.4 \mathrm{~b}$ & $14.0 \mathrm{ab}$ \\
\hline Aluminum plastic (APM) & $23.3 \mathrm{a}$ & $7.2 \mathrm{~b}$ & $2.0 \mathrm{~b}$ & $11.6 \mathrm{~b}$ \\
\hline \multicolumn{5}{|l|}{ Insecticide (kg a.i./ha) } \\
\hline Disulfoton $(3.4)$ & & $16.8 \mathrm{~b}$ & & \\
\hline Oxamyl $(0.28)$ & & $14.0 \mathrm{~b}$ & & \\
\hline Oxamyl $(0.56)$ & & $12.8 \mathrm{~b}$ & & \\
\hline Dimethoate $(0.56)$ & $21.5 \mathrm{a}$ & $10.8 \mathrm{~b}$ & & \\
\hline Methamidaphos (0.28) & & & $2.4 \mathrm{~b}$ & \\
\hline Methamidaphos $(0.56)$ & & $7.0 \mathrm{~b}$ & & \\
\hline Methamidaphos $(0.84)$ & & & $2.0 \mathrm{~b}$ & \\
\hline Methamidaphos $(0.84)+$ APM & & & $0.6 \mathrm{~b}$ & \\
\hline Bifenthrin $(0.07)$ & & $5.2 \mathrm{~b}$ & & \\
\hline Acephate $(0.56)$ & $23.5 \mathrm{a}$ & & $3.6 \mathrm{~b}$ & \\
\hline Esfenvalerate $(0.056)$ & $25.7 \mathrm{a}$ & & & \\
\hline
\end{tabular}

In each year, each value is the average of six, five, and five observation dates, respectively. Values followed by the same letter are not significantly different by Tukey's HSD test $(P=0.05)$.

Table 2. Average number of thrips per five tomato blooms, 1988.

\begin{tabular}{lrrrrrr}
\hline & \multicolumn{7}{c}{ No. thrips $^{2}$} \\
\cline { 2 - 7 } Treatment & 17 May & 24 May & 31 May & 6 June & 14 June & 22 June \\
\hline Mulch & & & & & & \\
$\quad$ Bare-ground untreated & $6.8 \mathrm{~b}$ & $9.8 \mathrm{~b}$ & $10.0 \mathrm{a}$ & $10.0 \mathrm{a}$ & $30.3 \mathrm{a}$ & $36.3 \mathrm{a}$ \\
$\quad$ Black plastic & $9.8 \mathrm{~b}$ & $22.8 \mathrm{~b}$ & $21.0 \mathrm{a}$ & $19.5 \mathrm{a}$ & $45.5 \mathrm{a}$ & $49.5 \mathrm{a}$ \\
$\quad$ White plastic & $21.0 \mathrm{a}$ & $50.3 \mathrm{a}$ & $15.5 \mathrm{a}$ & $11.8 \mathrm{a}$ & $84.8 \mathrm{a}$ & $62.0 \mathrm{a}$ \\
$\quad$ Aluminum plastic & $1.8 \mathrm{~b}$ & $14.3 \mathrm{~b}$ & $14.8 \mathrm{a}$ & $10.3 \mathrm{a}$ & $44.5 \mathrm{a}$ & $54.5 \mathrm{a}$ \\
Insecticide (kg a.i./ha) & & & & & & \\
$\quad \begin{array}{l}\text { Dimethoate (0.56) } \\
\text { Acephate (0.56) }\end{array}$ & $4.0 \mathrm{~b}$ & $23.0 \mathrm{~b}$ & $9.5 \mathrm{a}$ & $15.3 \mathrm{a}$ & $35.3 \mathrm{a}$ & $42.3 \mathrm{a}$ \\
$\quad$ Esfenvalerate (0.056) & $2.5 \mathrm{~b}$ & $20.5 \mathrm{~b}$ & $20.0 \mathrm{a}$ & $9.0 \mathrm{a}$ & $35.5 \mathrm{a}$ & $53.5 \mathrm{a}$ \\
& $9.0 \mathrm{~b}$ & $22.8 \mathrm{~b}$ & $18.3 \mathrm{a}$ & $12.3 \mathrm{a}$ & $56.8 \mathrm{a}$ & $35.0 \mathrm{a}$ \\
\hline
\end{tabular}

$\overline{{ }^{2}}$ Values in the same column followed by the same letter are not significantly different by Tukey's- HSD test $(P=0.05)$. 
presented only as an indication of their relative abundance in this study. No statistical sampling was attempted.

Incidence of TSW virus was very low each year, and no statistical differences were found among treatments. There were no differences among treatments in fruit numbers or weight in the marketable, nonmarketable, catfaced, or total fruit categories on any date or during any year. Likewise, there were no differences in percent marketable fruit, percent catfaced fruit, average fruit weight, or average marketable fruitweight. In 1989, when all fruit were harvested on one date, there were no differences among the treatments in the number or percentage of small, medium, large, or catfaced fruit. However, when all plastic mulch treatments were compared with all bareground treatments, the bare-ground treatments had a greater percentage of catfaced fruit. In 1990 there was a weak correlation (Pearson correlation coefficient $=0.67, P=0.07$ ) between thrips population and the percentage of catfaced fruit.

\section{Discussion}

White plastic is often used on lateplanted tomatoes when black plastic may cause excessive soil heating (Decoteau et al., 1986; Loy et al., 1989). Our results indicate that white plastic mulch is more attractive to thrips than any of the other treatments included in this experiment. The attractiveness of white plastic was greater early in the season and declined with time. This decline in the effects of mulch color is consistent with that found by Scott et al. (1989). As tomato plants grew, more and more surface area of plastic mulch was covered by foliage.

No differences in thrips population were found on tomatoes grown on aluminum or black plastic mulch or on tomatoes treated with any of the

Table 3. Average number of thrips per five tomato blooms, 1989.

\begin{tabular}{lrrrrr}
\hline \hline & \multicolumn{5}{c}{ No. thrips $^{2}$} \\
\cline { 2 - 6 } Treatment & 25 May & 31 May & 7 June & 14 Junc & 22 June \\
\hline Mulch & & & & & \\
$\quad$ Bare-ground untreated & $18.0 \mathrm{~b}$ & $9.0 \mathrm{~b}$ & $27.8 \mathrm{ab}$ & $19.8 \mathrm{ab}$ & $19.3 \mathrm{ab}$ \\
$\quad$ Black plastic & $10.3 \mathrm{~b}$ & $4.3 \mathrm{~b}$ & $6.3 \mathrm{~b}$ & $7.0 \mathrm{~b}$ & $12.0 \mathrm{ab}$ \\
$\quad$ White plastic & $64.3 \mathrm{a}$ & $34.3 \mathrm{a}$ & $43.8 \mathrm{a}$ & $51.8 \mathrm{a}$ & $33.3 \mathrm{a}$ \\
Aluminum plastic & $8.8 \mathrm{~b}$ & $2.0 \mathrm{~b}$ & $3.3 \mathrm{~b}$ & $11.3 \mathrm{~b}$ & $11.0 \mathrm{ab}$ \\
Insecticide (kg a.i./ha) & & & & & \\
Disulfoton (3.4) & $13.3 \mathrm{~b}$ & $7.0 \mathrm{~b}$ & $15.0 \mathrm{ab}$ & $28.5 \mathrm{ab}$ & $20.3 \mathrm{ab}$ \\
Dimethoate (0.56) & $13.3 \mathrm{~b}$ & $3.5 \mathrm{~b}$ & $15.5 \mathrm{ab}$ & $14.8 \mathrm{~b}$ & $6.7 \mathrm{ab}$ \\
$\quad$ Methamidaphos $(0.56)$ & $10.8 \mathrm{~b}$ & $3.0 \mathrm{~b}$ & $6.8 \mathrm{~b}$ & $7.5 \mathrm{~b}$ & $7.0 \mathrm{ab}$ \\
Bifenthrin (0.07) & $7.0 \mathrm{~b}$ & $2.8 \mathrm{~b}$ & $5.8 \mathrm{~b}$ & $6.0 \mathrm{~b}$ & $4.5 \mathrm{~b}$ \\
Oxamyl $(0.28)$ & $22.5 \mathrm{~b}$ & $5.3 \mathrm{~b}$ & $4.0 \mathrm{~b}$ & $20.8 \mathrm{ab}$ & $17.5 \mathrm{ab}$ \\
Oxamyl (0.56) & $10.8 \mathrm{~b}$ & $12.8 \mathrm{~b}$ & $7.3 \mathrm{~b}$ & $21.0 \mathrm{ab}$ & $12.0 \mathrm{ab}$ \\
\hline
\end{tabular}

'Values in the same column followed by the same letter are not significantly different by Tukey's HSD test $(P=0.05)$.

Table 4. Average number of thrips per five tomato blooms, 1990.

\begin{tabular}{|c|c|c|c|c|c|}
\hline \multirow[b]{2}{*}{ Treatment } & \multicolumn{5}{|c|}{ No. thrips ${ }^{2}$} \\
\hline & 13 June & 21 June & 29 June & 6 July & 13 July \\
\hline \multicolumn{6}{|l|}{ Mulch } \\
\hline Bare-ground untreated & $8.5 \mathrm{a}$ & $7.0 \mathrm{~b}$ & $7.0 \mathrm{~b}$ & $2.5 \mathrm{a}$ & $1.8 \mathrm{a}$ \\
\hline Black plastic & $5.8 \mathrm{a}$ & $6.3 \mathrm{~b}$ & $3.2 \mathrm{~b}$ & $1.0 \mathrm{a}$ & $1.0 \mathrm{a}$ \\
\hline White plastic & $18.3 \mathrm{a}$ & $52.0 \mathrm{a}$ & $30.5 \mathrm{a}$ & $1.0 \mathrm{a}$ & $6.5 \mathrm{a}$ \\
\hline Aluminum plastic (APM) & $2.5 \mathrm{a}$ & $4.3 \mathrm{~b}$ & $1.3 \mathrm{~b}$ & $0.8 \mathrm{a}$ & $1.0 \mathrm{a}$ \\
\hline \multicolumn{6}{|l|}{ Insecticide (kg a.i./ha) } \\
\hline Methamidaphos $(0.28)$ & $1.5 \mathrm{a}$ & $8.3 \mathrm{~b}$ & $1.5 \mathrm{~b}$ & $0.3 \mathrm{a}$ & $0.5 \mathrm{a}$ \\
\hline Methamidaphos $(0.84)$ & $0.8 \mathrm{a}$ & $7.0 \mathrm{~b}$ & $1.0 \mathrm{~b}$ & $1.0 \mathrm{a}$ & $0.0 \mathrm{a}$ \\
\hline Orthene $(0.56)$ & $6.0 \mathrm{a}$ & $7.8 \mathrm{~b}$ & $2.3 \mathrm{~b}$ & $1.5 \mathrm{a}$ & $0.5 \mathrm{a}$ \\
\hline Methamidaphos + APM $(0.84)$ & $0.5 \mathrm{a}$ & $0.8 \mathrm{~b}$ & $1.0 \mathrm{~b}$ & $0.3 \mathrm{a}$ & $0.3 \mathrm{a}$ \\
\hline
\end{tabular}

"Values in the same column followed by the same letter are not significantly different by Tukey's HSD test $(P=0.05)$. insecticides. None of the treatments were effective in reducing the total thrips population below that found in the control.

Sampling technique is very important when monitoring thrips populations. Scott et al. (1989) and Greenough (1985) used yellow sticky traps to sample thrips populations. Yellow sticky traps are effective only for adults of species that are attracted to yellow. We used actual counts of adult and immature thrips in tomato blooms. This technique has the advantage of accounting for all immatures and adults feeding on the tomato bloom.

The range of thrips populations encountered in this experiment caused no differences in the quantity, quality, or earliness of tomato harvest. Tomatoes with high thrips populations (white plastic mulch treatment) set the same number and size of fruit as tomatoes with lower thrips populations (all other treatments). Therefore, in the absence of TSW, thrips control on tomato was not justified in our study.

More disease incidence data is required to determine what degree of thrips control is necessary to decrease the incidence of TSW. The lack of significant thrips control by any of the treatments in this experiment suggests that vector control will be difficult.

Catfacing of tomatoes can be caused by several factors (Peirce, 1987; Watterson, 1985). The absence of a strong correlation between thrips population and catfacing suggests that the thrips populations encountered in this study were not a major factor in causing catfacing of tomato fruit. However, the weak correlation between thrips population and catfacing seen in 1990 suggests that, under certain conditions, thrips may (along with other factors) contribute to catfacing. Controlled population experiments are needed to clarify this issue.

In 1989 the plastic mulch treatments had a lower percentage of catfaced fruit than the bare-ground treatments. There was excessive rainfall during the 1989 experiment (48.7 $\mathrm{cm}$ from 1 May to 30 June), and rapid fruit growth following excessive soil moisture can result in catfaced fruit (Watterson, 1985). The plastic mulch may have resulted in more stable soil moisture conditions than the bareground plots. Whatever the reason, the presence or absence ofplastic mulch 
had a greater effect on catfacing than did thrips population in 1989.

\section{Acknowledgements}

We thank Marla Akridge, Paul Yates, and Li Ming for assistance in data collection and Joe Chamberlin for assistance with thrips identification.

\section{Literature Cited}

Decoteau, D.R., D.D. Daniel, M.J. Kasperbauer, and P.G. Hunt. 1986. Colored plastic mulches and tomato morphogenesis. Proc. Natl. Agr. Plastics Congr. 19:240-248.

Greenough, D.R. 1985. Aluminum-surfaced mulch and disease resistance: Approaches to the control of tomato spotted wilt virus in solanaceous crops. MS Thesis, Louisiana State Univ., Baton Rouge.

Hagan, A.K., J.R. Weeks, R.T. Gudauskas, and W.S. Gazaway. 1987. Tomato spotted wilt virus found in Alabama peanut fields. Alabama Agr. Expt. Sta., Auburn Univ. Highlights Agr. Res. 34(1):8.

Loy, J.B., J. Lindstrom, S. Gordon, D. Rudd, and O.S. Wells. 1989. Theory and development of wavelength selective mulches. Proc. Natl. Agr. Plastics Congr. 21:193197.

Peirce, L.C. 1987. Vegetables-Characteristics, production and marketing. Wiley, Toronto. p. 313-314.

Scott, S.J., P.J. McLeod, F.W. Montgomery, and C.A. Handler. 1989. Influence of reflective mulch on incidence of thrips (Thysanoptera: Thripidae: Phlaeothripidae) in staked tomatoes. J. Entomol. Sci. 24(4):422-427.

Watterson, J.C. 1985. Tomato diseases, a practical guide for seedsmen, growers, and agricultural advisors. Petoseed Co., Saticoy, Calif. p. 38

Wilkinson, L. 1989. SYSTAT: The system for statistics. SYSTAT, Inc., Evanston, Ill. 